\title{
Party Expenditure and Electoral Prospects: A National Level
}

\section{Analysis of Britain ${ }^{1}$}

\author{
Justin Fisher
}

\section{London Guildhall University}

The effectiveness of campaign spending is a hotly contested issue. Much of that debate concentrates upon predetermined or assumed campaign periods. Yet, in a party and electoral system such as Britain, parties are continually campaigning. Party expenditure may therefore have a constant and cumulative effect. This article examines whether increased party spending at the national level is electorally significant. It analyses annual data from 1959 to 1994 and concludes that there is insufficient consistent evidence wholly to support this proposition.

Keywords: elections, party finance, incumbents, challengers, national

\section{INTRODUCTION}

Herbert Alexander, a prominent writer in the field of political finance, has argued that political power is built upon three constituencies: the electoral, the financial and the organisational. Money is an element of political power because it buys what is not or cannot be volunteered (Adamany \& Agree, 1975, p. 3; Alexander, 1984, p. 3). Moreover, money is the most important constituent because finance also dominates the organisational and electoral aspects of political life (Alexander, 1989, pp. 10-12). The importance of money in politics is fundamental, for it can affect political spending and contributes to debates concerning political equality. Some 
claim that money distorts this equality. They argue that since all citizens have an equal right to political participation, so all interests should receive financial support in proportion to their adherents. The reality is, however, that wealthy groups are represented beyond the proportion of their number. Inequalities in money are greater than any other inequalities of the resources that go into political life, because money can buy virtually all of the resources that are given directly by citizens (Paltiel, 1981; Adamany \& Agree, 1975). Money is essential for the very existence and survival of political parties, but debate has tended to suggest that disparities in the financial endowment of parties distorts electoral competition in favour of the most wealthy party. The logic of this argument is simple - namely that increased spending capacity provides parties with greater opportunities to promote themselves to voters and the exploitation of such opportunities will result in electoral payoffs. Consequently, it is argued that unregulated political finance fails to guarantee a level playing field in the competition for power, thus undermining the right to equal political participation.

Claims that party expenditure may be electorally significant are based upon the idea that money is a constant sum. The implicit assumption is that a resource (in this case money) will be used with equal degrees of skill. However, there is a good theoretical case to be made against this assumption. For example, if I were to give $£ 100$ each to three election candidates with the instruction to use that money to promote their candidature, it might be that each would choose a different manner in which to promote themselves. Candidate A might produce 1,000 leaflets, Candidate B might produce one large poster and Candidate C might spend the money on a loudhailer for his or her campaign vehicle. Despite 
the initial sums the same, their electoral impact might not be identical. Money would not therefore be a constant sum. Even if all three candidates produced 1,000 leaflets, there is no guarantee that the leaflets would be equally well received or that they would have an equal impact on the vote, since the leaflets could be produced with varying degrees of skill. Notwithstanding these arguments however, there is some evidence to suggest that party spending does have an impact upon electoral outcomes.

\section{COMPARATIVE EVIDENCE}

Jacobson (1980) tests the significance of financial endowment in terms of electoral success. Using data from congressional elections in the United States, he argues that if money is significant in the electoral prospects of candidates, then it will be of greater significance for challengers than for incumbents. All other things being equal, voters will favour candidates about whom they have the most information. Since incumbents use their office to publicise themselves, such candidates should require less publicity (and therefore funds) during an election. Moreover, incumbents will be likely to spend less if they feel that their re-election is reasonably assured. Conversely a challenger, who has not enjoyed the benefits of incumbent publicity, will have greater need for campaign finance (Jacobson, 1980, pp. 36-37). As a result, money spent by challengers should have a greater electoral impact than that spent by incumbents. Jacobson's testing tends to confirm his hypothesis. Moreover, whilst his analysis is centred around individual candidates in congressional elections, he argues that the incumbency effect upon the relative need for campaign expenditure will also be reflected in broader terms (Jacobson, 1980, p. 37). 
Jacobson's work has not been without its critics, however. Green and Krasno $(1988,1990)$ argue that incumbent spending is more significant than Jacobson had claimed and that challenger spending is less significant and subject to diminishing returns. Gerber (1998, p.402) also questions Jacobson's position. He argues firstly, that while incumbents may be well-known and therefore have an information advantage, challengers can spend money to address new issues which may not be on the established political agenda. Thus, challengers have an theoretical advantage of establishing themselves as champions of a particular cause. Secondly, campaigning may not only be positive, promoting one's own cause, but also negative - highlighting damaging information about an opponent. Thus incumbents have an advantage where challengers are less well known since they have a greater opportunity to shape preferences about that candidate. Thirdly, incumbents in theory should be more effective in their spending since they will typically be better organised. Finally, Gerber draws upon simple pleas to 'common sense' - if incumbent spending is so futile, why do so many raise and spend so much money? This final claim is certainly the least robust of Gerber's criticisms, since the mere fact that people do something does not prove its effectiveness, even if the assumptions of the significance of campaign spending may suggest rationality on the part of these candidates.

Gerber (1998, p.401) also questions Jacobson's approach by suggesting the idea that campaign spending is exogenous is an erroneous assumption. He points out that most models of party spending have assumed the exogenous nature of spending levels. In fact, Jacobson (1990, p. 335) accepts that his model may not 
be entirely watertight. In particular, he highlights the fact that the relationship between money and electoral popularity may be reciprocal. Thus, there is likely to be a relationship between how a candidate is likely to perform on election day and how much he or she can raise. In turn, this will affect how much he or she can spend, which in turn may affect how well he or she performs electorally.

In Britain there is repeated evidence at constituency level that general election party expenditure can influence electoral outcomes (Johnston, 1985; Johnston, 1986; Johnston \& Pattie 1995; Pattie, Johnston \& Fieldhouse, 1995). These analyses show that on average the Conservatives spend most per constituency (Johnston \& Pattie, 1995, p. 262) and the greatest proportion of the maximum permitted by electoral law (Johnston \& Pattie, 1995, p. 263; Pattie, Johnston \& Fieldhouse, 1995, pp. 971-972). For all parties, increased spending at constituency level improves electoral performance within that constituency (Johnston \& Pattie, 1995, p. 269). That said, the effect is stronger amongst challengers than amongst incumbents, where the impact of increased expenditure is mixed (Pattie, Johnston \& Fieldhouse, 1995, pp. 979-980). This is consistent with Jacobson's argument that high incumbent spending may be interpreted as a sign of electoral weakness, rather than strength since incumbents tend to spend more when under a sustained challenge. 


\section{NATIONAL LEVEL ANALYSIS}

In this article, the intention is to move from examining local and candidate level electoral effects to those at national level. Thus, the focus of this analysis will differ from the existing literature in three principal respects. First, it will focus upon national level spending and national level vote share. Secondly, unlike the candidate-based analyses in the work from the United States, this analysis focuses upon parties, in a manner similar to Johnston and his colleagues. Thirdly, the focus is not simply upon official campaigns, but upon annual levels of electoral popularity. Notwithstanding, these differences, however, the analysis will attempt to establish whether the findings of these previous studies hold in the national environment.

The contention in this article is that party campaigning is something of a constant, rather than an activity existing only at certain points of a cycle. Party spending will necessarily be linked to this activity. Thus, whilst parties concentrate most attention upon General Elections and to lesser extent, the other elections occurring during this cycle, they do not only operate and campaign at these times. Parties are continually competing to win the support of public opinion. To use a sporting analogy, parties are not simply playing friendlies between General Elections, they are in the qualifying stages for the World Cup. Party expenditure may be seen therefore, as having longer-term impact upon electoral choice rather than just a short-term impact at General Elections.

Moreover, continually good party performance, especially at the electoral level, will enhance voters' opinions of that party when they come to make electoral 
choices. An analogy would be with a corporation that performed consistently well in a variety of markets. Consistent performance would promote consumer confidence in that brand. Such confidence in the party will assist in voters' decision-making. For example, under a Downsian model, should ideological distance between parties be such that a voter is unable to make a choice, then the voter will judge the credibility of parties to pursue their programmes (Downs, 1957, pp.41-45; Laver, 1997, pp.99-100). It is likely that continually good performance will contribute to such evaluations of credibility.

Party expenditure at the national level in Britain Running a political party is an expensive activity. Competitive political parties require funds for three purposes: to fight election campaigns, to maintain viable interelection organisations and to provide research and other assistance to the leadership and representatives of the party (Paltiel, 1981, p. 139). As the 1966 Barbeau Committee Report on Canadian Political Finance observed:

'The elector cannot make a sensible choice unless he is well informed. Keeping the electorate well informed means using the great communications media: radio, television, newspapers, printed flysheets, billboards etc. If these media are to be used well, parties and candidates must spend very considerable sums of money. The sums are essential expenses in informing the public.' (Quoted in Ewing, 1992, p. 47) 
Yet, in order to achieve these aims, political parties require considerable amounts of money. In short, politics is an expensive activity and money is indispensable (Alexander, 1989, p. 13; Ewing, 1992, p. 61 ;Paltiel, 1981, p. 138; Fisher, 1996a, p. 200). A regular flow of income is vital for the survival of political parties. This then leads to the institutionalisation of political parties and the development and maintenance of parties' central bureaucracies (Panebianco, 1988, pp. 58-59).

Panebianco's claims are borne out in the British case. Most spending is routine: generally constituting around $80 \%$ of Conservative and Labour central expenditure. Even the 1992 general election year, routine expenditure by the Conservatives was far greater than that spent upon campaigning. The second point to note is that whilst most campaigning is still undertaken in general elections, a significant amount occurs in between. Thus, $£ 2.2$ million was spent by the Conservatives in the non-general election year $1993 / 94$ and $£ 737,000$ by Labour; whilst in the European election year of 1994/95, the Conservatives spent $£ 4.4$ million and Labour $£ 2.5$ million. The effect is that constant levels of spending will help ensure that parties remain prominent in voters' minds.

[Figure 1 About Here]

Figure 1 illustrates levels of real terms central expenditure over the period of the analysis. Spending peaks at General Elections and troughs directly afterwards, with the peaks and troughs being more pronounced in the case of the Conservative Party. Secondly, there is significant spending between General Elections. Thirdly, we can see that as at local level, Conservative spending has 
consistently been above that of Labour, to the extent that until 1974 Conservative troughs were higher that Labour peaks. More recently, the spending gap has closed somewhat, though Conservative spending in the run-up to the 1992 General Election was notably high. ${ }^{2}$

[Figure 2 About Here]

Figure 2 gives a clearer indication of the closing spending gap, showing Labour expenditure expressed as a percentage of that of the Conservatives. The reference line at $100 \%$ indicates equal spending. Year on year, the electoral playing field has become more level, at least for the two principal parties, but the Conservatives have retained an advantage at General Elections. Of course, if elected, this allows for the advantages of incumbency.

Hypotheses and methodology

The general problem to be tested is whether a party's annual expenditure can influence its annual popularity in opinion polls. The models employed are based upon the work of Johnston et al (Johnston, 1985; Johnston, 1986; Johnston \& Pattie 1995; Pattie, Johnston \& Fieldhouse, 1995) ${ }^{3}$ and Jacobson (Jacobson, 1980; Jacobson, 1990). Thus, the hypothesis is that electoral popularity is function of party spending, spending by the principal opponent and existing party strength.

$P O L L=\alpha+\beta_{1} P S+\beta_{2} P E-\beta_{3} O P E+e($ Model 1) 
Where: $\alpha$ is the constant; POLL is the share of the poll for Party $a$; $P S$ is the electoral strength of Party $a$ (Measured here by the poll rating one year previously); $P E$ is expenditure by Party $a$; $O P E$ is expenditure by Party $b ; e$ is the error term; $\beta_{1-3}$ are regression coefficients. In this model, the expectation is that $P E$ and $P S$ will be positively signed, suggesting that a party's expenditure and its existing electoral strength will have a positive effect on its vote share. Conversely, the expectation is that $O P E$ will be negatively signed, suggesting that spending by the principal opponent will have a negative impact.

Analysing national level spending presents some methodological difficulties, however. First, there is no pre-defined campaign period. Spending is not regulated and unlike at local level, parties are not required to submit returns for campaign expenditure. Second, as with all analyses of spending, one cannot adequately control for 'non-partisan' political campaigning. For example, during the 1992 General Election, the public-sector union NALGO mounted a strong anti-Conservative campaign, which took out more press advertisements than the Conservatives and Liberal Democrats combined. However, since the union was not affiliated to the Labour Party and since the campaign did not explicitly endorse any party, there are methodological problems in measuring the positive effects at least of such campaigns. This is a common problem. Gidlund notes that in Sweden, despite the fact that the Liberal party had sought to limit corporate income and the Conservative Party eliminate it completely, corporate donations continued to be made to business groups which ran nominally independent political campaigns for which the political support was plain. Moreover, this form of support is in a state of rapid development (Gidlund, 1991). Such developments have also in 
the past been evident with the rise of corporate PACs in the USA, and in the past in West Germany, Norway and Japan (Nassmacher, 1993, p. 253).

This analysis however, is able to compensate for the first problem and partially so for the second by examining party performance on an annual basis. Since political parties do not only operate in electoral cycles but as more of a constant, we can alleviate difficulties presented by the absence of pre-defined campaign periods. ${ }^{4}$ Secondly, whilst we cannot entirely control for 'non-partisan' effects, this analysis can at least assess whether the standing of parties can be affected on a year-on-year basis by the amounts that parties spend. Non-partisan spending by way of contrast is more likely to be concentrated at the time of key - usually general - elections.

Jacobson's key assumption, however as we have seen is that campaign spending will be of greater significance for challengers rather than incumbents. On this basis, he hypothesises that the amount spent by challengers will have a greater impact on the outcome of an election than that spent by incumbents, controlling for incumbent's expenditure and the previous electoral strength of the challenger. The changes to the basic model are then as follows:

$C P=\alpha+\beta_{1} C P S+\beta_{2} C E-\beta_{3} I E+e($ Model 2)

Where: $\alpha$ is the constant; $C P$ is challenger's share of the poll; $C P S$ is the electoral strength of the challenger (Measured here by the poll rating one year previously); $C E$ is the challenger's expenditure; $I E$ is the incumbent's expenditure; $e$ is the error term; $\beta_{1-3}$ are regression coefficients. In this model, the 
expectation is that $C E$ and $C P S$ will be positively signed, suggesting that the challenging party's expenditure and its existing electoral strength will have a positive effect on its vote share. Conversely, the expectation is that $I E$ will be negatively signed, suggesting that spending by the incumbent party will have a negative impact.

The equation is then reformulated to examine whether expenditure is less important for incumbents. It also allows us to examine the claims of both Green and Krasno $(1988,1990)$ and Gerber (1998) that incumbent expenditure will be more likely to yield electoral payoffs.

$I P=\alpha+\beta_{1} I P S+\beta_{2} I E-\beta_{3} C E+e($ Model 3)

Where: $\alpha$ is the constant; IP is incumbent's share of the poll; IPS is the electoral strength of the incumbent (Measured here by the poll rating one year previously); $I E$ is the incumbent's expenditure; $C E$ is the challenger's expenditure; $e$ is the error term; $\beta_{1-3}$ are regression coefficients. In this model, the expectation is that $I E$ and IPS will be positively signed, suggesting that the incumbent party's expenditure and its existing electoral strength will have a positive effect on its vote share. Conversely, the expectation is that $C E$ will be negatively signed, suggesting that spending by the challenging party will have a negative impact.

If these data were cross-sectional, a common procedure to differentiate the effects of opposition and incumbency would be to simply divide the data by those criteria and compare regressions. However, the use of time-series presents 
a problem since splitting the data entails interrupting the time-series. One solution to this problem is to employ an intercept dummy variable to denote incumbency or opposition, together with a dummy interaction variable. This is produced by multiplying the dummy variable by the relevant explanatory variable and captures differences in the slope (Gujarati, 1992, pp 260-78). By using these techniques, problems of interrupted time-series are avoided. ${ }^{5}$

Since parties produce accounts annually, there is no way of ascertaining whether certain periods of the year generate more income than others. For this reason, all the data are taken as a yearly figure, or, where more frequent time intervals occur, a mean for the calendar year is produced. ${ }^{6}$ Since the time period is relatively long, there is no need to build lags into the models as the period of one year provides a sufficient internal lag. The following variables are used:

Conservative central expenditure in real terms (standardised at 1963 prices by the RPI); Conservative opinion poll rating; Labour central expenditure in real terms (standardised at 1963 prices by the RPI); Labour opinion poll rating. ${ }^{7}$

For all analyses, Ordinary Least Squares (OLS) is employed. Since the models include a lagged endogenous variable (poll rating one year previously), the problem of autocorrelation can be alleviated. In all tables, unstandardised regression coefficients are reported together with $\mathrm{t}$ statistics and their associated levels of significance. 


\section{RESULTS}

The results for Model 1 are illustrated in Table 1. This covers the whole period for both parties. Taking the impact on Conservative poll ratings, Conservative expenditure is correctly signed as having a positive impact and Labour spending is correctly signed as negative. Neither parameters however are statistically significant. For Labour poll ratings, neither expenditure variables has any discernible impact, confirmed by the fact that both fail to reach statistical significance. Only previous electoral strength provides any significant effect in either model. Thus, without controls for incumbency or challenge, it seems that increased party spending may not be effective.

\section{[Table 1 About Here]}

In tables 2 and 3, the impact of spending is analysed according the status of the parties as incumbents or opposition as described in Models 2 and 3. Dummy intercept and dummy interaction variables are employed to denote party status. For example the following model is employed to examine periods of Conservative incumbency:

$$
\begin{aligned}
& \text { CONPOLL }_{t}=\alpha+\beta_{1} \text { CONPOLL }_{t-1}+\beta_{2} D_{t}+\beta_{3} \text { CONEXP }_{t}-\beta_{4} L A B E X P_{t}+ \\
& \beta_{5}\left(D_{t} * \operatorname{CONEXP}_{t}\right)-\beta_{6}\left(D_{t} * L A B E X P_{t}\right)+e_{t}
\end{aligned}
$$

Where: $\alpha$ is the constant; $C O N P O L L_{t}$ is Conservative poll ratings; $C O N P O L L_{t-1}$ is Conservative poll ratings lagged by one year; $D_{t}$ is the dummy intercept term ( $1=$ Conservative incumbent and $0=$ Conservative opposition); CONEXP $P_{t}$ is 
Conservative real terms expenditure; $L A B E X P_{t}$ is Labour real terms expenditure; $\left(D_{t} * C O N E X P_{t}\right)$ is the interaction variable of $C O N E X P_{t}$ multiplied by $D_{t}$; $\left(D_{t} * L A B E X P_{t}\right)$ is the interaction variable of $L A B E X P_{t}$ multiplied by $D_{t} ; e_{t}$ is the error term; $\beta_{1-6}$ are regression coefficients. The same form of model is then run on Labour poll ratings. Results are reported for both opposition and incumbency for ease of interpretation.

Table 2 illustrates the effects of spending by both parties on Conservative poll ratings during periods of Conservative opposition and incumbency. During periods of Conservative opposition, Labour spending is correctly signed as having a negative effect upon Conservative poll ratings. Conservative spending is however, incorrectly signed, suggesting that as the Conservative Party increases its spending in opposition, it performs less well in the opinion polls - a counter-intuitive finding. Both parameters however, fail to reach statistical significance.

The results in Table 2 do, however indicate that increased spending by the Conservative Party when it is the incumbent does appear to improve poll ratings, though that effect is small. All other variables remaining equal, an increase in spending of $£ 1,000$ per annum at 1963 prices ( $£ 10,560$ at 1994 prices) would produce a $0.004 \%$ increase in Conservative poll ratings. Spending by Labour in opposition is also correctly signed, suggesting that an increase in Labour spending hinders the Conservatives. This parameter is not however, statistically significant. 
[Table 2 About Here]

Table 3 illustrates the effects of spending by both parties on Labour poll ratings. When Labour is in opposition, Conservative expenditure is correctly signed as having a negative impact upon Labour poll ratings but is not statistically significant. Labour's spending is incorrectly negatively signed as having a negative impact on Labour poll ratings. This is counter-intuitive but again, it is not statistically significant. When Labour is the incumbent party, its expenditure is correctly signed, suggesting a positive impact. Conservative spending in opposition is however, incorrectly signed as also having a positive impact. That said, neither parameters are statistically significant. Overall, expenditure by either party does not appear to affect Labour's poll ratings.

Thus, it appears that the central thrust of Jacobson's findings - that challenger spending is most significant - does not hold in these scenarios. Challenger spending fails to reach statistical significance in both sets of estimations. Model 3 does however produce estimates which fit the broad hypothesis, namely that in periods of Conservative incumbency at least, the party is marginally more popular when it spends more money. This is consistent with both Green and Krasno and Gerber's assertions that it is incumbent rather than challenger spending which is most likely to yield electoral payoffs. That said, this finding does not hold however in periods of Labour incumbency.

[Table 3 About Here] 
An initial overall interpretation of these results might be therefore, that spending at national level had little demonstrable electoral impact. There are, however, certain factors which should be borne in mind. First, the analysis attempted to control for non-partisan campaigning by examining electoral or poll success on a year on year basis; the logic being that non-partisan campaigning of significance tends to occur at the times of general elections. However, it cannot wholly eliminate these effects, nor can it control for partisanship within the press which though heightened at general elections, still continues throughout the electoral 'cycle'. This is a potential problem, since press and media coverage can affect parties' abilities to promote their message. Opinion is divided upon the electoral effects of the press (see, for example Curtice \& Semetko, 1994). Nevertheless estimates have been made which suggest that 'party funding in kind' can potentially be significant. One such estimate utilises Precis, a technique developed in the United States and used by Ross Perot in 1992. The technique assesses not just column inches, but the size and position of articles as well as assessments of their positivity or negativity for the client (in this case political parties). Using this technique, Linton estimates that favourable newspaper coverage in the 1992 General Election was worth $£ 16$ million to the Conservatives and $£ 5$ million to Labour (Linton, 1994, pp. 29-31). If this technique is reliable, then of course the models tested here do not incorporate this additional 'expenditure'.

Yet in spite of these potential drawbacks, the results may well illustrate a very real phenomenon, namely that resources and party expenditure are not a constant sum. Despite that fact that parties spend different amounts, they may also do so with differing degrees of skill and effectiveness. The results should not be 
interpreted as implying that national party expenditure makes little or no difference to electoral outcomes; clearly a party that spent nothing would be likely to fare badly. It is simply to suggest that expenditure differentials per se may not be as critical as is often argued (Linton, 1994; Ewing, 1992), since parties, like any other organisation or individual will use money with varying degrees of skill. After all, in anecdotal terms, whilst Labour spent less than the Conservatives in the 1987 general election, it was generally judged to have 'won' the campaign. It lost the election.

\section{CONCLUSIONS}

The results reported here suggest that increased party expenditure can have a positive effect, but that this is difficult to show on a consistent basis. Certainly, it would appear that the Conservatives can help maintain their national profile when in government (measured by opinion polls) by increasing party expenditure. Overall however, it appears that the case suggesting that national party expenditure has a positive effect on electoral fortunes is difficult to sustain. That said, the data are limited to an extent by the fact that they need to be taken as an annual observation. This means that we cannot capture shorter term electoral effects of increases in party spending. Moreover, annual data restricts the number of observations. For those reasons, some caution at least should be registered. However, the results here are indicative and do suggest that party spending at national level may not be as effective in electoral terms as is often suggested. $^{8}$ 
A consequence of this is that the commonly argued case for state funding; that of a 'level electoral playing field', is more difficult in empirical terms to justify. Notwithstanding the added problems of attempting to enforce ceilings upon national expenditure, these results indicate that between the main two British parties at least, the advantage of increased national party expenditure is unclear. That is not to say, of course, that state funding of parties is undesirable - merely that disparities in national party expenditure may not provide a convincing case for its extended adoption. 
Figure 1

Conservative and Labour Central Expenditure (Real Terms) 1959-1994

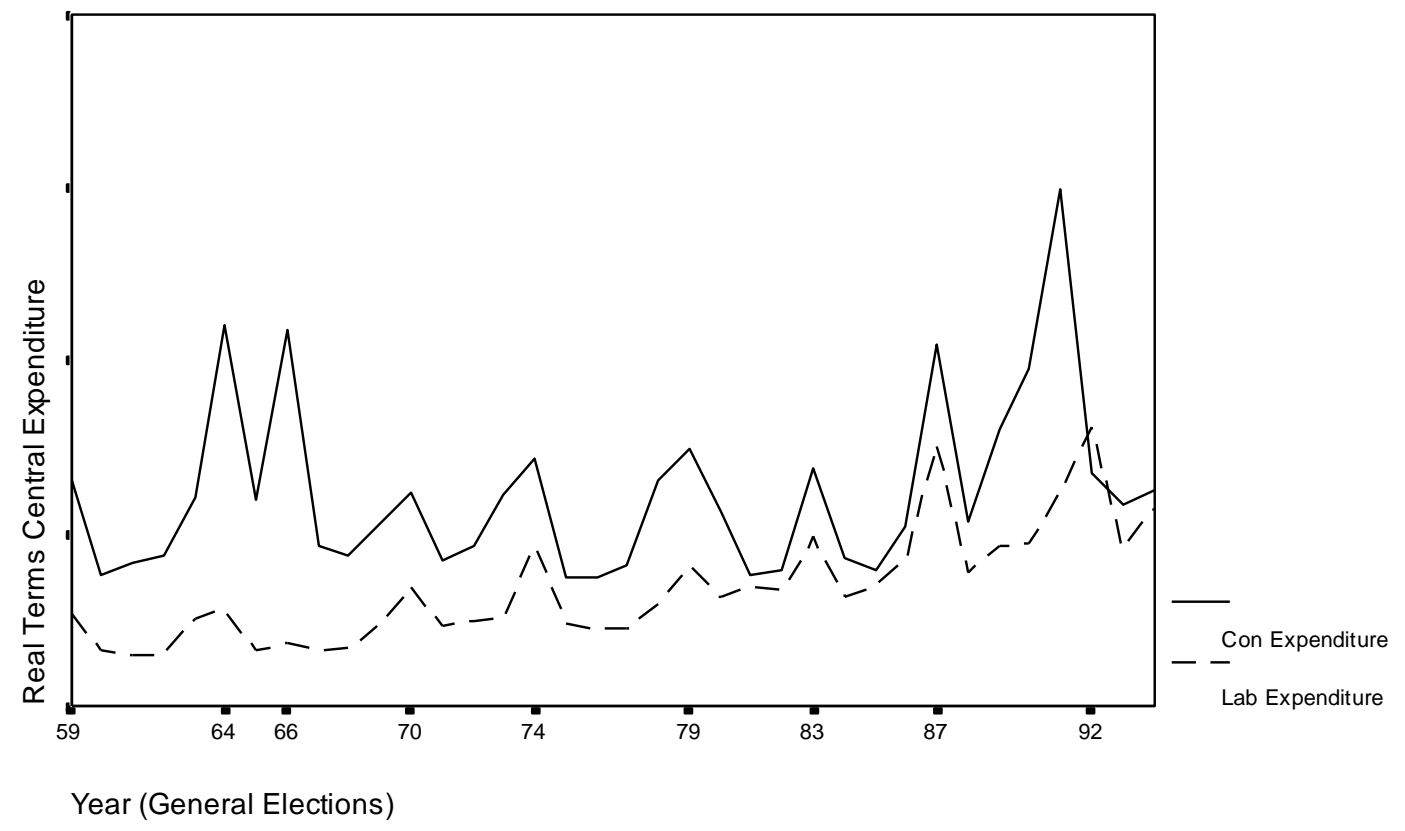


Figure 2

Labour Expenditure as a Percentage of Conservative Expenditure 19591994

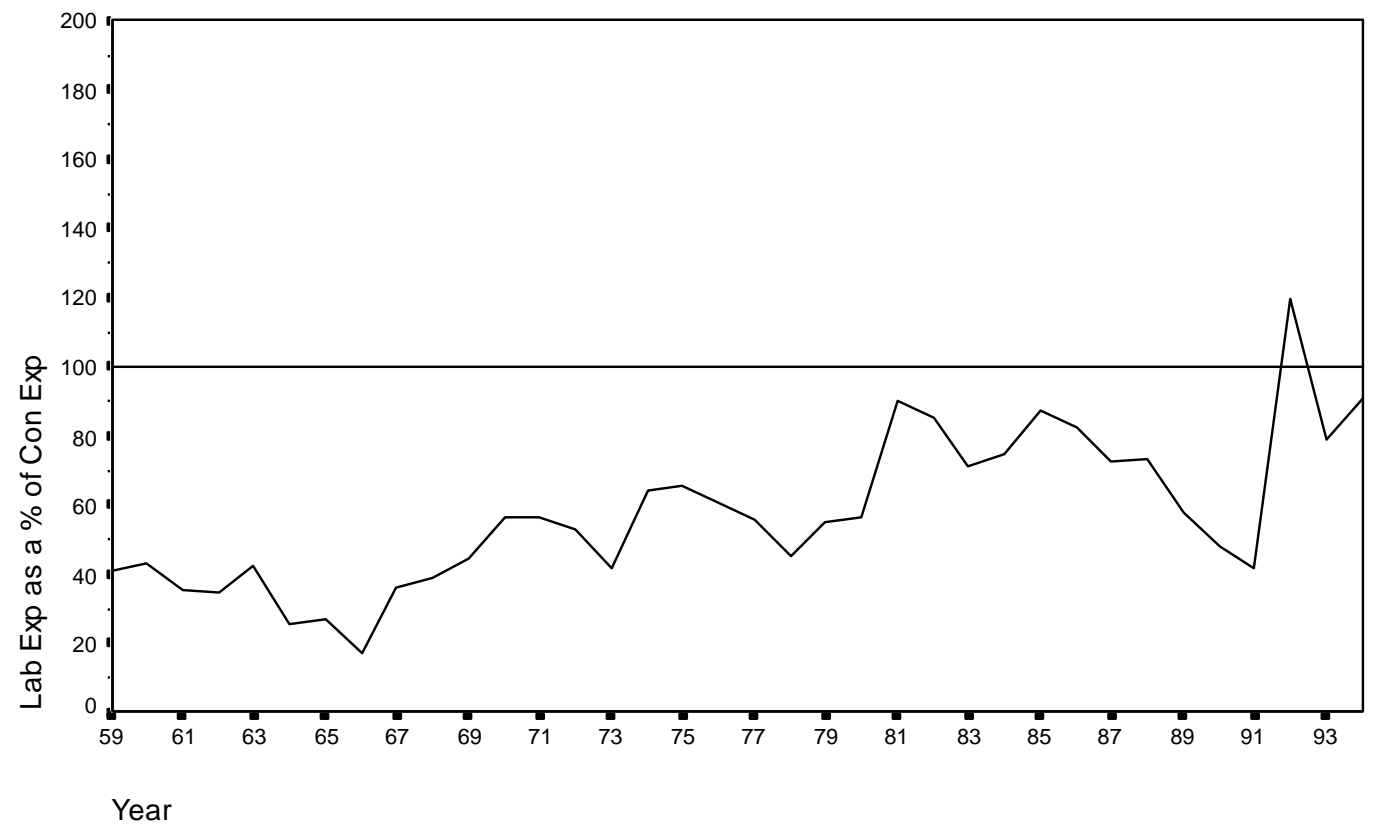


Table 1

The Impact of Spending on Conservative and Labour Poll Ratings Model 1

\begin{tabular}{|c|c|c|c|c|c|c|}
\hline & \multicolumn{3}{|c|}{ Conservative Poll } & \multicolumn{3}{|c|}{ Labour Poll } \\
\hline & $\mathrm{b}$ & $\mathrm{t}$ & $\mathrm{p}$ & $\mathrm{b}$ & $\mathrm{t}$ & $\mathrm{p}$ \\
\hline Constant & 12.159 & $(1.551)$ & & 12.991 & $(1.839)$ & $*$ \\
\hline Poll Rating ${ }_{t-1}$ & 0.666 & $(4.056)$ & $* * *$ & 0.664 & (4.010) & $* * *$ \\
\hline Conservative Expenditure & 0.003 & (1.487) & & 0.001 & $(0.323)$ & \\
\hline Labour Expenditure & -0.004 & $(-1.271)$ & & 0.000 & $(0.087)$ & \\
\hline Adjusted $r^{\frac{1}{2}}$ & & 0.407 & & & 0.348 & \\
\hline $\begin{array}{l}\text { Durbin-Watson } \\
\mathrm{n}=35\end{array}$ & & 1.358 & & & 1.553 & \\
\hline significant at 0.01 level & & & & & & \\
\hline significant at 0.05 level & & & & & & \\
\hline significant at 0.1 level & & & & & & \\
\hline
\end{tabular}


Table 2

The Impact of Spending on Conservative Poll Ratings Controlling for Status

\begin{tabular}{|c|c|c|c|c|c|c|}
\hline & \multicolumn{3}{|c|}{$\begin{array}{l}\text { Conservative Opposition - } \\
\text { Model } 2\end{array}$} & \multicolumn{3}{|c|}{$\begin{array}{l}\text { Conservative Incumbent - } \\
\text { Model } 3\end{array}$} \\
\hline & $\mathrm{b}$ & $\mathrm{t}$ & $\mathrm{p}$ & $\mathrm{b}$ & $\mathrm{t}$ & $\mathrm{p}$ \\
\hline Constant & 7.731 & $(1.164)$ & & 25.365 & $(3.290)$ & $* * *$ \\
\hline Poll Rating ${ }_{t-1}$ & 0.657 & $(4.763)$ & **** & 0.657 & $(4.763)$ & $* * *$ \\
\hline Incumbency/Opposition Dummy & 17.635 & $(3.456)$ & **** & -17.635 & $(-1.329)$ & $* * *$ \\
\hline Conservative Opposition Expenditure & -0.004 & $(-1.456)$ & & $\mathrm{x}$ & $\mathrm{x}$ & \\
\hline Labour Incumbent Expenditure & -0.008 & $(-1.127)$ & & $\mathrm{x}$ & $\mathrm{x}$ & \\
\hline Conservative Incumbent Expenditure & $\mathrm{x}$ & $\mathrm{x}$ & & 0.004 & $(2.402)$ & $* *$ \\
\hline Labour Opposition Expenditure & $\mathrm{x}$ & $\mathrm{x}$ & & -0.002 & $(-0.593)$ & \\
\hline Adjusted $\mathrm{r}^{2}$ & & 0.589 & & & 0.589 & \\
\hline $\begin{array}{l}\text { Durbin-Watson } \\
\mathrm{n}=35\end{array}$ & & 1.334 & & & 1.334 & \\
\hline *** $\quad$ significant at 0.01 level & & & & & & \\
\hline $\begin{array}{ll}* * & \text { significant at } 0.05 \text { level } \\
* & \text { significant at } 05 \text { level }\end{array}$ & & & & & & \\
\hline
\end{tabular}


Table 3

The Impact of Spending on Labour Poll Ratings Controlling for Status

\begin{tabular}{|c|c|c|c|c|c|c|}
\hline & \multicolumn{3}{|c|}{$\begin{array}{c}\text { Labour Opposition - } \\
\text { Model } 2\end{array}$} & \multicolumn{3}{|c|}{$\begin{array}{c}\text { Labour Incumbent - } \\
\text { Model } 3\end{array}$} \\
\hline & $\mathrm{b}$ & $\mathrm{t}$ & $\mathrm{p}$ & $\mathrm{b}$ & $\mathrm{t}$ & $\mathrm{p}$ \\
\hline Constant & 3.071 & $(0.346)$ & & 14.617 & $(2.058)$ & $* *$ \\
\hline Poll Rating $_{\mathrm{t}-1}$ & 0.687 & $(4.182)$ & $* * *$ & 0.687 & $(4.182)$ & $* * *$ \\
\hline Incumbency/Opposition Dummy & 11.546 & $(1.925)$ & $*$ & -11.546 & $(-1.925)$ & $*$ \\
\hline Labour Opposition Expenditure & -0.001 & $(0.166)$ & & $\mathrm{x}$ & $\mathrm{x}$ & \\
\hline Conservative Incumbent Expenditure & -0.000 & $(-0.218)$ & & $\mathrm{x}$ & $\mathrm{x}$ & \\
\hline Labour Incumbent Expenditure & $\mathrm{x}$ & $\mathrm{X}$ & & 0.007 & $(0.793)$ & \\
\hline Conservative Opposition Expenditure & $\mathrm{x}$ & $\mathrm{x}$ & & 0.005 & $(1.373)$ & \\
\hline Adjusted $\mathrm{r}^{2}$ & & 0.368 & & & 0.368 & \\
\hline $\begin{array}{l}\text { Durbin-Watson } \\
n=35\end{array}$ & & 1.407 & & & 1.407 & \\
\hline significant at 0.01 level & & & & & & \\
\hline$* * \quad$ significant at 0.05 level & & & & & & \\
\hline
\end{tabular}




\section{REFERENCES}

Adamany, D.W. \& Agree, G.E. (1975) Political Money. Baltimore, John Hopkins University Press.

Alexander, H.E. (1984) Financing Politics. Washington, CQ Press.

Alexander, H. (1989) Money and politics: rethinking a conceptual framework. In Comparative Political Finance in the 1980s, ed. Alexander, H., pp. 9-23. Cambridge, Cambridge University Press.

Butler, D \& Butler, G. (1994) British Political Facts 1900-1994. London, MacMillan.

Curtice, J. \& Semetko, H. (1994) Does it matter what the papers say? In Labour's Last Chance? eds. Heath, A. Jowell, R. \& Curtice, J., pp. 43-63. Aldershot, Dartmouth.

Denver, D. \& Hands, H. (1997) Challengers, Incumbents and the Impact of Constituency Campaigning in Britain. Electoral Studies, 16,175-193, Downs, A. (1957) An Economic Theory of Democracy. New York, Harper and Row.

Ewing, K. (1992) Money, Politics \& Law. Oxford, Clarendon Press.

Fisher, J. (1996a) British Political Parties. Hemel Hempstead, Prentice Hall.

Fisher, J. (1996b) Party Finance. In The Conservative Party, ed. Norton, P., pp. 157-169. Hemel Hempstead, Prentice Hall.

Gerber, A. (1998) Estimating the Effect of Campaign Spending on Senate Election Outcomes Using Instrumental Variables. American Political Science Review 92, 401-412. 
Gidlund, G. (1991) The nature of public financing in Nordic states. In The Public Purse and Political Parties, ed. Wiberg, M., pp. 173-186. Helsinki, Finnish Political Science Association.

Green, D.P. \& Krasno, J.S. (1988) Salvation for the Spendthrift Incumbent: Reestimating the Effects of Campaign Spending in House Elections. American Journal of Political Science 32, 884-907.

Green, D.P. \& Krasno, J.S. (1990) Rebuttal to Jacobson's “New Evidence for Old Arguments”. American Journal of Political Science 34, 363-372.

Gujarati, D. (1992) Essentials of Econometrics. Singapore, McGraw Hill. Jacobson, G.C. (1980) Money in Congressional Elections. New Haven, Yale University Press).

Jacobson, G.C. (1990) The Effects of Campaign Spending in House Elections: New Evidence for Old Arguments. American Journal of Political Science, 34, 334-362.

Johnston R. \& Pattie, C. (1995) The Impact of Spending on Party Constituency Campaigns in Recent British General Elections. Party Politics 1, 261-273. Johnston, R.J. (1985) The Geography of English Politics. London, Croom Helm. Johnston, R.J. (1986) A Further Look at British Political Finance. Political Studies 34, 466-473.

Laver, M. (1997) Private Desires, Political Action. London, Sage.

Linton, M. (1994) Money and Votes. London, IPPR.

Nassmacher, K.H. (1993) Comparing Party and Campaign Finance in Western Democracies. In Campaign and Party Finance in North America and Western Europe, ed. Gunlicks, A.B., pp. 233-267. Boulder, Westview Press. 
Paltiel, K.Z. (1981) Campaign Finance: Contrasting Practices and Reforms. In Democracy at the Polls, eds. Butler, D., Penniman, H.R. \& Ranney, A., pp.138173. Washington, American Enterprise Institute.

Panebianco, A. (1988) Political Parties. Organization and Power. Cambridge, Cambridge University Press

Pattie, C, Johnston, R \& Fieldhouse, E. (1995) Winning the Local Vote: The Effectiveness of Constituency Campaign Spending in Britain, 1983-1992. American Political Science Review. 89, 969-983.

Pinto-Duschinsky, M. (1981) British Political Finance 1830-1980. London, American Enterprise Institute.

Pinto-Duschinsky, M. (1985) Trends in British Political Funding 1979-1983 Parliamentary Affairs. 38, 329-347.

Pinto-Duschinsky, M. (1989) Trends in British Party Funding 1983-1987. Parliamentary Affairs. 42, 197-212. 
1 I am most grateful for the valuable advice provided by both the anonymous referees and the editors in the preparation of this article.

2 It appears from the graph that Labour spending outstripped that of the Conservatives in 1992. The reason for this is that the Conservative financial year has run to the end of March since 1967 whereas Labour's runs to the end of December. For comparison, therefore, Conservative spending is classified as being in the year in which the financial year is largely concerned. For example, the financial year 1991/92 is classified as being 1991 since 9 months fell in that year. Thus, much of the spending by the Conservatives in the run-up to the 1992 election is classified as having taken place in 1991.

3 Johnston \& Pattie (1995) calculate the dependent variable as the share of the two party vote, rather than vote share overall. All estimates were run using both vote share and share of the two party vote i.e. Labour share of Conservative + Labour. The results were almost identical.

$4 \quad$ Although party spending is continual, it is nevertheless clear that it peaks at the time of General Elections. It has been suggested, therefore that a dummy variable be included in the models to capture election year effects. This is problematic since there is no defined point at which election spending begins. The impact of the dummy variable would therefore be unpredictable. Nevertheless, the models were tested with such a dummy variable, but its inclusion had no substantive impact upon the results. When interaction terms are used in regression analysis, problems of collinearity amongst independent variables sometimes arise (See Denver \& Hands, 1997, p.192). In order to check the reliability of the analysis, the data were split into relevant periods of incumbency and opposition. The results were virtually identical, indicating that the findings using the intercept dummy variable and dummy interaction variable are reliable. Since the data are taken as an annual observation, incumbency is defined by the party being in government for the greater proportion of the calendar year.

7 The sources of these data are, Butler \& Butler (1994), Fisher (1996a;1996b), Gallup and Pinto-Duschinsky $(1981 ; 1985 ; 1989)$.

Aggregate control variables of alternative predictors of party support have not been used in this analysis. The reason for this is twofold. First, the analysis seeks to establish whether spending could potentially have an impact. As the results show, this is generally not the case. Secondly, the most obvious aggregate control variable, personal economic evaluations, cannot be used as that time series only commences in 1974. Since there is no consistent empirical evidence that objective economic indicators are useful over this entire period, it was decided not to include them. 